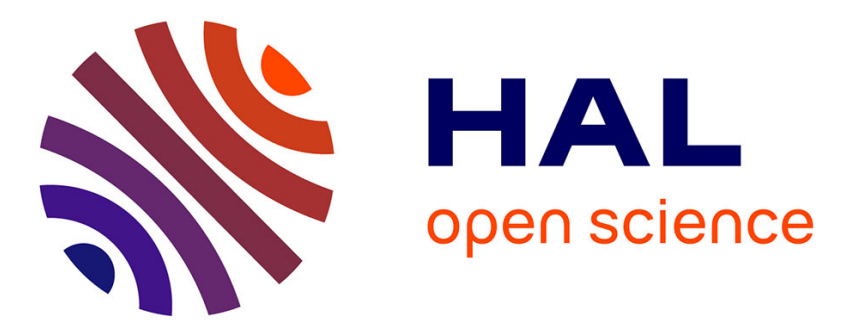

\title{
Rapid and quantitative assessment of trout spermatozoa motility using stroboscopy
}

\author{
Marie-Paule Cosson, Roland Billard, J.L. Gatti, R. Christen
}

\section{To cite this version:}

Marie-Paule Cosson, Roland Billard, J.L. Gatti, R. Christen. Rapid and quantitative assessment of trout spermatozoa motility using stroboscopy. Aquaculture, 1985, 46 (1), pp.71-75. 10.1016/00448486(85)90178-4 . hal-01608554

\section{HAL Id: hal-01608554 \\ https://hal.science/hal-01608554}

Submitted on 2 Jun 2020

HAL is a multi-disciplinary open access archive for the deposit and dissemination of scientific research documents, whether they are published or not. The documents may come from teaching and research institutions in France or abroad, or from public or private research centers.
L'archive ouverte pluridisciplinaire HAL, est destinée au dépôt et à la diffusion de documents scientifiques de niveau recherche, publiés ou non, émanant des établissements d'enseignement et de recherche français ou étrangers, des laboratoires publics ou privés.

\section{다(1)(2)}

Distributed under a Creative Commons Attribution - ShareAlikel 4.0 International 


\title{
Short Communication
}

\section{RAPID AND QUANTITATIVE ASSESSMENT OF TROUT SPERMATOZOA MOTILITY USING STROBOSCOPY}

\author{
MARIE-PAULE COSSON ${ }^{1}$, R. BILLARD ${ }^{2}$, J.L. GATTI ${ }^{1}$ and R. CHRISTEN ${ }^{1}$ \\ ${ }^{1}$ Station Zoologique, UR 250, F-06230 Villefranche-sur-Mer (France) \\ ${ }^{2}$ Station de Physiologie Animale, I.N.R.A., F-78350 Jouy-en-Josas (France)
}

(Accepted 27 September 1984)

\section{ABSTRACT}

Cosson, M.-P., Billard, R., Gatti, J.L. and Christen, R., 1985. Rapid and quantitative assessment of trout spermatozoa motility using stroboscopy. Aquaculture, 46: 71-75.

An objective technique is proposed for rapid quantitative assessment of spermatozoa motility using stroboscopy. Milt is first prediluted $(1: 100)$ in a solution of $40 \mathrm{mM} \mathrm{KCl}, 85$ $\mathrm{m} M \mathrm{NaCl}, 30 \mathrm{~m} M$ Tris-HCl, at $\mathrm{pH} 9.2$. One $\mu$ l of this solution is placed on a slide coated with BSA, diluted with $20 \mu \mathrm{l}$. of an activation solution (125 $\mathrm{mM} \mathrm{NaCl}, 30 \mathrm{mM}$ Tris $-\mathrm{HCl}, \mathrm{pH} 9.2$ ), and the beating frequency of the flagella is immediately recorded using stroboscopic illumination. At $20^{\circ} \mathrm{C}$, initial flagellum beating was around $60 \mathrm{~Hz}$ and regularly dropped to $15 \mathrm{~Hz}$ within $30 \mathrm{~s}$ (phase 1). Afterwards, $5-15 \%$ of the spermatozoa kept beating for $1 \mathrm{~min}$ or more at low frequency, 12.5-7.5 $\mathrm{Hz}$ (phase 2). The initial beating frequency was highly dependent on the temperature, and rose from 30 $\mathrm{Hz}$ at $5^{\circ} \mathrm{C}$ to $48 \mathrm{~Hz}$ at $15^{\circ} \mathrm{C}$. The rate of inactivation also depended on the temperature; it increased between 5 and $20^{\circ} \mathrm{C}$ but seemed to decrease at $25^{\circ} \mathrm{C}$.

\section{INTRODUCTION}

Spermatozoa motility in fish is usually estimated by an arbitrary scale of intensity ranging from 0 to 5 (Hoyle et al., 1968; Sanchez-Rodriguez and Billard, 1977), by the duration of motility for a given intensity (Carpentier and Billard, 1978), or by a combination of these two parameters (Baynes et al., 1981). More objective measurements have been obtained with quasielastic diffusion of light (Dubois et al., 1975; Billard and Breton, 1976; Craig et al., 1983). However, this technique, integrating measurements over 1- to 5-min periods, is satisfactory only for spermatozoa such as those of guppy (Dubois et al., 1975) which have prolonged motility. It is not practical for trout spermatozoa which are motile for about $30 \mathrm{~s}$. Stroboscopy has been widely used to study flagellar movement. The present work shows that stroboscopy can be used to analyse quantitatively the decrease in motility of trout spermatozoa after dilution of milt in an activating medium. 
Rainbow trout (Salmo gairdneri) males weighing 700 to $1000 \mathrm{~g}$ were brought from the Simbille trout farm to the laboratory at Villefrancesur-Mer 2 weeks after the beginning of spermiation (second part of November). They were kept in running tap water at $10^{\circ} \mathrm{C}$ and fed with regular broodstock pellets $(7 \mathrm{~mm})$ at a daily rate of $1 \%$ of body weight. Milt was collected early in the morning or afternoon, kept on ice, and used within 2 to $3 \mathrm{~h}$.

Milt $\left(>10^{10}\right.$ spermatozoa $\left./ \mathrm{ml}\right)$ was prediluted $(1: 100)$ in a solution kept on ice ( $40 \mathrm{~m} M \mathrm{KCl}, 85 \mathrm{~m} M$ NaCl, $30 \mathrm{~m} M$ Tris- $\mathrm{HCl}$, pH 9.2). This solution was used because the spermatozoa remain immotile and retain their fertilizing capacity for long periods of time after dilution.

One $\mu$ l of the prediluted sperm was mixed with $20 \mu \mathrm{l}$ of an activation solution (125 $\mathrm{mM} \mathrm{NaCl}, 30 \mathrm{mM}$ Tris-HCl, $\mathrm{pH} \mathrm{9.2)} \mathrm{on} \mathrm{a} \mathrm{slide} \mathrm{coated} \mathrm{with}$ BSA. Motility was measured with stroboscopic illumination (ChadwickHelmuth Strobex) and dark-field optics ( $\times 16$ Zeiss lens). The sperm solution was scored for the percentage of motile spermatozoa and the frequency of flagellar movement. With some practice, the first measurement could be taken 4 to $5 \mathrm{~s}$ after dilution.

This standard procedure was used to measure the change in flagellar movement of 2 to 6 sperm samples from six different males; these measurements were taken at room temperature $\left(20^{\circ} \mathrm{C}\right)$. Frequency was measured at $5,10,15,20$, and $25^{\circ} \mathrm{C}$ to study the effect of temperature on motility.

\section{RESULTS}

When trout milt was diluted in an activation medium ( $\mathrm{NaCl} 125 \mathrm{~m} M$, pH 9.2), it instantly showed a high percentage of motile spermatozoa with a high frequency of flagellar movement but which quickly stopped swimming. On the other hand, when the spermatozoa were diluted in a medium with a high potassium concentration, they remained immotile but retained their ability to initiate movement upon redilution in an activation medium. Motility could still be initiated by redilution more than $2 \mathrm{~h}$ after incubation in a high $\mathrm{K}^{+}$medium, and the quality of the movement was indistinguishable from that of the control. Immediately after dilution (2-5 s post-mixing), almost $100 \%$ of the spermatozoa were motile with flagella beating at a uniform frequency. For about $30 \mathrm{~s}$ (phase 1), the frequency of flagellar beating decreased steadily and homogeneously in the population of spermatozoa; Fig. 1 shows the decrease in frequency with time. From the first part of the curve, a frequency of $60 \mathrm{~Hz}$ was extropolated for zero time (initial frequency). At $30 \mathrm{~s}$, the frequency declined to $15 \mathrm{~Hz}$ after a linear decrease of $15 \mathrm{~Hz} / 10 \mathrm{~s}$ (inactivation rate) during phase 1 . Thus, the majority of spermatozoa ( $80-95 \%$ depending upon the male) abruptly stopped swimming, while 5-15\% kept beating for $1 \mathrm{~min}$ or more 


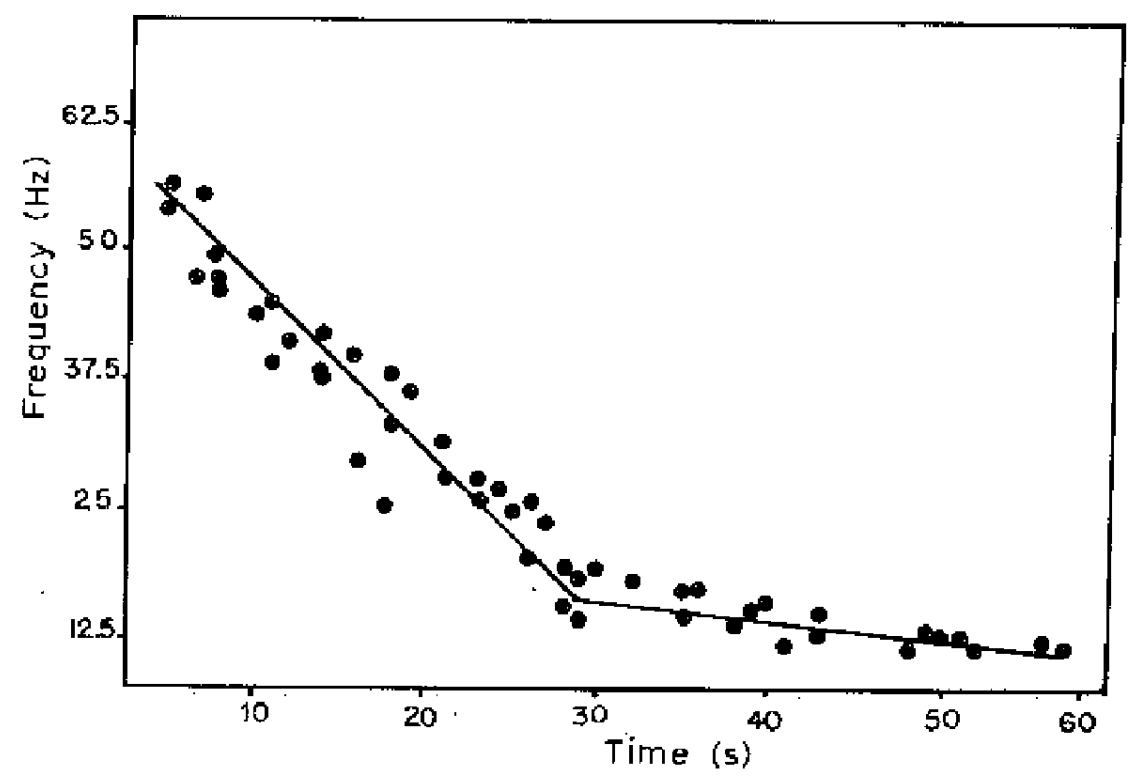

Fig. 1. The beating of flagella of trout spermatozoa, at $20^{\circ} \mathrm{C}$, as a function of time. The spermatozoa of one male were diluted in an activation medium and observed with a dark-field microscope and stroboscopic illumination (see text for explanation). Each dot represents one measurement. This figure shows that all motile spermatozoa had the same initial frequency and that this frequency decreased with time following a biphasic pattern.

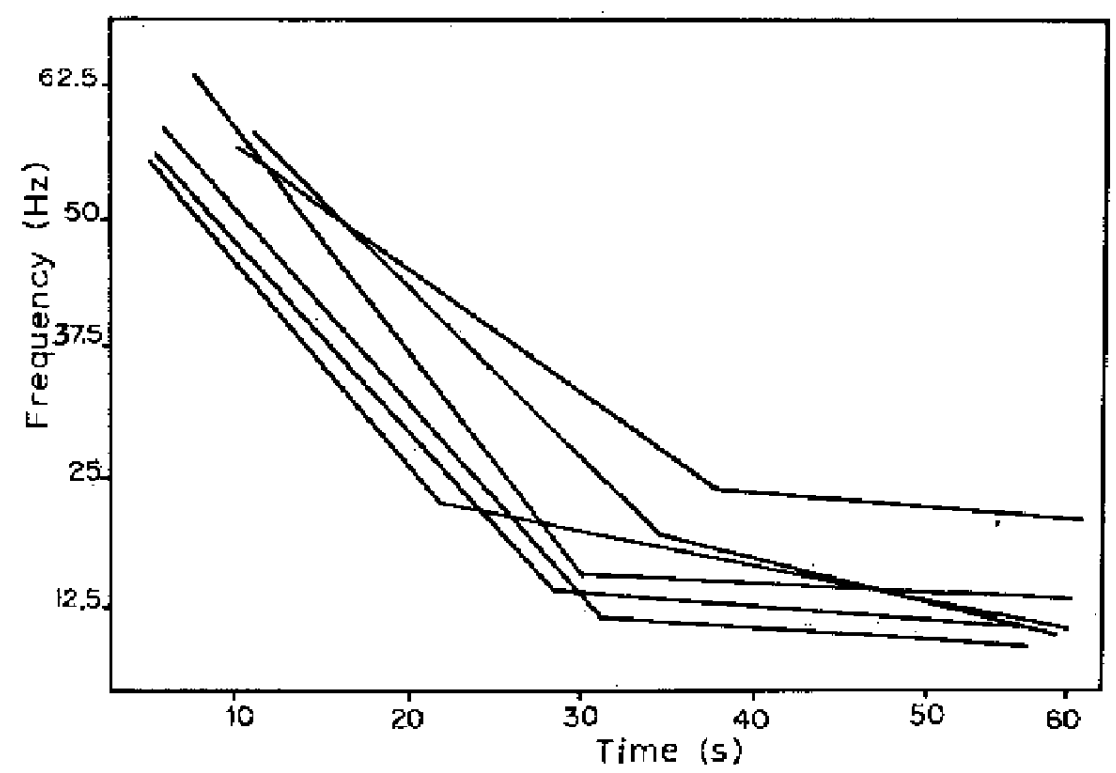

Fig. 2. The spermatozoa of six male trout, analysed as described in Fig. 1.

at low frequencies $(12.5$ to $7.5 \mathrm{~Hz}$ ), and spermatozoa velocity was greatly reduced (phase 2).

Measurements obtained with five other males showed a similar biphasic pattern (Fig. 2). Phase 1 lasted from 20 to $40 \mathrm{~s}$ with an initial frequency ranging between 60 and $72.5 \mathrm{~Hz}$ and inactivation rate of between 11.5 and $21.5 \mathrm{~Hz} / 10 \mathrm{~s}$. During phase 2, the frequency varied from 10 to 20 $\mathrm{Hz}$, and $5-20 \%$ of the spermatozoa were motile.

The initial beating frequeney depended greatly upon the temperature (Table I) with a particularly high rise in frequency between 10 and $15 \% \mathrm{C}$. The inactivation rate increased between 5 and $20^{\circ} \mathrm{C}$ but seemed to decrease at $25^{\circ} \mathrm{C}$. 
TABLE I

Frequency and decrease of flagellar movement as a function of temperature. The data were plotted as in Fig. 1 and the initial frequency of flagellar beating, as well as the inactivation rate, were calculated from the figure (see text for explanations)

\begin{tabular}{lll}
$\begin{array}{l}\text { Temperature } \\
\left({ }^{\circ} \mathrm{C}\right)\end{array}$ & $\begin{array}{l}\text { Initial frequency } \\
(\mathrm{Hz})\end{array}$ & $\begin{array}{l}\text { Inactivation rate } \\
(\mathrm{Hz} / 10 \mathrm{~s})\end{array}$ \\
\hline 5 & 30 & 6.2 \\
10 & 32.5 & 7.5 \\
15 & 46.5 & 15 \\
20 & 62.5 & 17.5 \\
25 & 51 & 21.5 \\
\hline
\end{tabular}

\section{DISCUSSION}

These results demonstrate that stroboscopic observation of trout spermatozoa is a very precise method for determining such parameters as: - the initial frequency of flagellar beating after dilution of spermatozoa in an activation medium;

- the inactivation rate of this frequency with time after dilution that occurs linearly from 20 to $40 \mathrm{~s}$ at $20^{\circ} \mathrm{C}$ (phase 1);

- the percentage of motile spermatozoa during phase 1 ;

- the duration of phase 1 ;

- the percentage of sperm showing prolonged movement with reduced beating frequency after phase 1 (phase 2);

- the frequency of the movement of these spermatozoa and the duration of phase 2.

We do not know yet how to relate these observations to the quality of spermatozoa for fertilization, but we plan to compare the behavior of spermatozoa from good or poor brood fish. These experiments were carried out at the beginning of the reproductive season, and preliminary observations were made towards the end of spermiation, when sperm quality decreased. Benau and Terner (1980) showed a decline in initial frequency and in the percentage of motile spermatozoa in phase 1. Phase 2 may also be important as a quality criterion since it varies from male to male and is sometimes absent at the end of the reproductive season.

These two phases of motility are in parallel with changes in the fertilizing ability of spermatozoa diluted in a saline solution and used to fertilize eggs at various times after dilution, provided that large quantities of spermatozoa are used (Billard et al, 1974; Billard, 1977). This indicates that spermatozoa are still able to fertilize eggs during phase 2 of motility.

The motility pattern is drastically altered by temperature; a maximal initial frequency was obtained in the 15 to $25^{\circ} \mathrm{C}$ range, as already reported by Billard and Breton (1976) who observed a frequency of $100 \mathrm{~Hz}$ at $20^{\circ} \mathrm{C}$ with the quasielastic light diffusion technique. At physiological temper- 
atures for trout $\left(5-10^{\circ} \mathrm{C}\right)$, the beating frequency was reduced but phase 1 lasted longer. These conditions may represent a maximal efficiency for fertilization since experiments carried out at different temperatures gave the best results at $5^{\circ} \mathrm{C}$ (Billard and Gillet, 1975).

\section{ACKNOWLEDGEMENTS}

This work was partly supported by a grant (RCP 656) from the Centre National de la Recherche Scientifique.

\section{REFERENCES}

Baynes, S.M., Scott, A.P. and Dawson, A.P., 1981. Rainbow trout, Salmo gairdneri Richardson, spermatozoa: effects of cations and $\mathrm{pH}$ on motility. J. Fish Biol., 19: $259-267$.

Benau, D. and Terner C., 1980. Initiation, prolongation, and reactivation of salmonid spermatozoa. Gamete Res., 3: 247-257.

Billard, R., 1977. Utilisation d'un système Tris-Glycocolle pour tamponner le dilueur d'insémination de truite. Bull. Fr. Piscic., 264: 102-112.

Billard, R. and Breton, B., 1976. Sur quelques problèmes de physiologie du sperme ches les poissons téléostéens. Rev. Trav. Inst. Pêches Marit., 40: 501-503.

Billard, R. and Gillet, C., 1975. Effets de la température sur la fécondation et la survie des gamètes chez la truite Arcen-ciel, Salmo gairdneri. Bull. Fr. Piscic., 259: 53-65.

Billard, R., Jalabert, B. and Breton, B., 1974. L'insémination artificielle de la truite Salmo gairdneri Richardson. III. Définition de la nature et de la molarité du tampon à employer avec les dilueurs d'insémination et de conservation. Ann. Biol. Anim. Biochim. Biophys., 14:611-621.

Carpentier, $P$. and Billard, R, 1978. Conservation à court terme des gamètes de Salmonidés à des températures voisines de $0^{\circ} \mathrm{C}$. Ann. Biol. Anim. Biochim. Biophys., 18: 1083-1088.

Craig, T., Blaber, A. and Hallett, F.R., 1983. Motility of spermatozoa of rainbow trout, Salmo gairdneri, in solutions of various salinities as studied by quasi-elastic light scattering. Biol. Reprod., 29: 1189-1193.

Dubois, M., Jouannet, P., Bergé, P., Volochine, B., Serres, C. and David, G., 1975. Méthode et appareillage de mesure objective de la mobilité des spermatozoídes humains. Ann. Phys, Biol, Méd., 9: 19-41.

Hoyle, R.J., Truscott, B. and Idler, D.R., 1968. Studies on freezing sperm of Atlantic salmon (Salmo salar). Fish. Res. Board Can., Tech. Rep. no. 93, 42 pp.

Sanchez-Rodriguez, M. and Billard, R., 1977. Conservation de la motilité et du pouvoir fécondant du sperme de la truite arc-en-ciel maintenu à des températures voisines de $0^{\circ} \mathrm{C}$. Bull. Fr. Piscic., 265: 144-152. 